Relations industrielles

Industrial Relations

\title{
Cunningham, Neil et Richard Johnstone, Regulating Workplace Safety: Systems and Sanctions
}

\section{Michel Pérusse}

Volume 55, numéro 2, 2000

URI : https://id.erudit.org/iderudit/051318ar

DOI : https://doi.org/10.7202/051318ar

Aller au sommaire du numéro

Éditeur(s)

Département des relations industrielles de l'Université Laval

ISSN

0034-379X (imprimé)

1703-8138 (numérique)

Découvrir la revue

Citer ce compte rendu

Pérusse, M. (2000). Compte rendu de [Cunningham, Neil et Richard Johnstone, Regulating Workplace Safety: Systems and Sanctions]. Relations industrielles / Industrial Relations, 55(2), 366-368. https://doi.org/10.7202/051318ar

Tous droits réservés (C) Département des relations industrielles de l'Université Laval, 2000
Ce document est protégé par la loi sur le droit d'auteur. L'utilisation des services d'Érudit (y compris la reproduction) est assujettie à sa politique d'utilisation que vous pouvez consulter en ligne.

https://apropos.erudit.org/fr/usagers/politique-dutilisation/ 
The authors acknowledge that a major problem with their research design, from the standpoint of conventional methodology, is the difficulty of making generalizations from a set of four case studies. However, the authors are very candid about their approach, revealing its limitations as well as specifying its advantages.

The book concludes by recognizing that Pay Equity as an instrument of legal reform illustrates the paradoxical role that law plays in American society. While the laws against gender based pay discrimination and sex segregation are shown to have positively affected explicitly sexist employment practices, this created the appearance that the law was available as a remedy against gender injustice in the work place. However, the application of these laws also entrenched a form of gender based wage inequality in organizations by allowing for the continuance of wage differences between traditionally male and female jobs. The authors call upon sociologists to construct programs of empirical research that better articulate the relationship between organizations, markets and wages so that they can produce more powerful explanations of pay discrimination than economists and legal theorists have advanced thus far. This could, in turn, lead to a change in the legal and regulatory climate. Certainly one of the most interesting aspects of the book is the insights it offers into the dynamics of law reform litigation and the use of social science, economic theory, and data.

Paula Knopf

Paula Knopf Arbitrations and Osgoode Hall Law School, York University

\section{Regulating Workplace Safety : Systems and Sanctions}

par Neil Cunningham et Richard Johnstone, Oxford : Oxford University Press, 1999, 423 p., ISBN 7-80198-268246.

Au départ, l'éditeur précise que la question au cœur de ce livre est de savoir comment la loi peut effectivement pénétrer les organisations pour les rendre plus sensibles aux efforts réglementaires. On est donc porté à croire, à craindre, qu'on va avoir affaire à des gens qui prônent une lourde réglementation comme moyen de résoudre les problèmes de santé et de sécurité dans les organisations et les entreprises. Mais rapidement les auteurs nous rassurent : ce qu'ils préconisent c'est non pas plus de règlements, mais des règlements plus intelligents, mieux ciblés pour être plus percutants.

Leur démarche repose sur une comparaison des systèmes législatifs et réglementaires en matière de santé et de sécurité du travail (SST), d'abord entre les diverses juridictions d'Australie, et qui fut ensuite élargie pour inclure la Grande-Bretagne, la Suède, le Danemark, les États-Unis et le Canada. Le tout est on ne peut mieux documenté, on n'a qu'à en juger par les 446 références. Pour étoffer certains points spécifiques de leur argumentation, les auteurs s'inspirent abondamment de l'Agence européenne pour la santé et la sécurité du travail et font également des rapprochements avec des réglementations connexes, comme dans le domaine de l'environnement, dans d'autres pays dont la Hollande. Et les autcurs, deux universitaires australiens notoires qui ont aussi des liens en Grande-Bretagne (Oxford) pour un et aux États-Unis (Berkeley) pour l'autre, sont particulièrement bien placés pour procéder à ces comparaisons et rapprochements.

La problématique est la suivante. Les règlements basés sur les spécifications (ex. un certain type de garde sur un certain type de machine), ainsi que les règlements basés sur les résultats (ex. 85 $\mathrm{dB}(\mathrm{A})$ comme niveau maximal de bruit dans un certain environnement) ont 
atteint les limites de leur utilité, et ce pour au moins quatre grandes raisons. Premièrement, leur mise en vigueur nécessite beaucoup de ressources alors que les ressources des inspectorats tendent plutôt à diminuer. Deuxièmement, ces règlements reposent sur une approche de confrontation entre les inspectorats et les milieux de travail, or les auteurs affirment que les États-Unis, qui misent le plus lourdement sur cette approche de confrontation, sont également le pays où les résultats en SST laissent le plus à désirer parmi tous les pays qui ont fait l'objet de cette comparaison. Troisièmement, rien dans ces types de règlements $n$ 'incite les entreprises à aller au delà du strict minimum légal. Finalement, ces types de règlements sont mieux adaptés aux traditionnels risques physiques de l'industrie manufacturière; ils sont beaucoup moins efficaces en ce qui concerne les nouveaux problèmes de santé et de sécurité, notamment le stress découlant d'une mauvaise organisation du travail ou les problèmes musculo-squelettiques résultant d'un piètre aménagement du poste de travail ou d'un travail répétitif.

Pour les auteurs, ce qui donne des résultats, ce sont les règlements basés sur un processus, sur un système. Un tel système implique un cadre de gestion du type de celui qui est sous-jacent à la norme ISO 14001 en gestion environnementale, ou qui est sous-entendu dans le système appelé « Contrôle Interne », en vigueur dans les pays scandinaves, particulièrement en Suède. Ce sont les entreprises dotées de tels cadres de gestion qui sont les plus performantes en SST. C'est pourquoi les auteurs proposent d'instaurer une réglementation incitant certaines entreprises (ex. les plus performantes, les plus grandes) à se doter d'un véritable système de gestion de la SST. C'est ce que les auteurs appellent leur Ligne Deux (Track Two). Dans les faits, il s'agit d'une façon de miser sur l'auto-régulation. Mais comme l'autorégulation pure peut donner lieu à des faux-fuyants, les auteurs préconisent des mécanismes de contrôle pour s'assurer qu'il ne s'agit pas d'une vaste opération de papier.

On doit quand même, suggèrent-ils, maintenir la voie réglementaire usuelle «Track One » pour les autres, ou pour les entreprises qui n'ont pas mérité la confiance mise en eux, pour les récalcitrants ou les récidivistes graves, pour ces entreprises qui sont en infraction flagrante à des règlements connus et qui occasionnent ainsi des risques graves. Les auteurs suggèrent aussi de durcir ce qu'ils appellent la pyramide des incitatifs et des sanctions. Selon eux, la pyramide devrait comporter une gamme plus grande d'incitatifs et de sanctions mineures à la base de la pyramide, et des sanctions plus sévères, incluant des sanctions criminelles, au sommet de la pyramide, avec des règles et consignes transparentes pour escalader les paliers, et une escalade rapide pour les récalcitrants notoires et les récidivistes graves.

Les huit chapitres et l'annexe se lisent relativement bien, une fois qu'on a réussi à s'acclimater au langage juridique parfois un peu hermétique. La principale ombre au tableau, ce sont les notes infrapaginales, qui en fait se trouvent groupées à la fin de chaque chapitre. Et il y en a beaucoup : 1047 pour être précis. Le chapitre 6 en compte 238 à lui seul, et une phrase en page 114 en compte 4 en autant de lignes. Pour quiconque les consulte au fur et à mesure la lecture devient très saccadée; il est alors très difficile de suivre le fil de l'argument que les auteurs développent. D'autant plus que certaines de ces notes constituent des commentaires très substantiels (parfois jusqu'à une page, écrite en petits caractères serrés). Comme un très grand nombre de ces notes sont en fait des références, elles devraient être intégrées au corps du texte selon la méthode usuelle; quant aux notes qui constituent en fait des commentaires substantiels, les auteurs devraient trouver des moyens de les incorporer à même le texte. Il resterait 
alors considérablement moins de notes, et la lecture s'en trouverait de beaucoup facilitée.

Cependant, il s'agit somme toute d'un problème bien mineur par rapport à la très grande qualité du fond, à l'originalité du système réglementaire proposé. Ce système, soit dit en passant, fait une place de plus en plus grande à la participation des employés et de leurs représentants. Même les États-Unis, traditionnellement réfractaires à une telle participation, semblent vouloir modifier leurs règlements dans cette direction. Il semble donc y avoir un vent de changement en matière de santé et sécurité au travail : bonne nouvelle pour ceux et celles qui font carrière dans ce domaine!

Michel Pérusse

Université Laval et

Prévention des accidents, Noranda

\section{Organizational Diagnosis and Assessment: Bridging Theory and Practice by Michael I. HARRISSON and Arie SHIROM, Thousand Oaks, Calif.: Sage Publications, 1999, 486 p., ISBN 0-8089-5511-1.}

This book invites planned change or organizational development practitioners and consultants to depart from a specific frame of reference, explicit or not, for which they have acquired skills and to adopt instead what the authors call a "sharp-image diagnosis" framework. This type of diagnosis begins with a broad frame at the outset (the scouting phase of an intervention), in order to get a comprehensive or holistic view of what is going on in the client organization, of the gaps between the actual state and the desired state held by the different stakeholders, and of the sources of these inefficiencies. The diagnosis then moves beyond this opening phase by "zooming-in" on one or more specific features of the organization. For that purpose, a particular conceptual apparatus or model and data-gathering methodology are required, used within the broad framework as a complement to it or as a concomitant way of uncovering specific dimensions and challenges of the client organization.

To develop their new approach, the authors divide their work in five parts, each containing four or five chapters, except the last, which contains the concluding chapter. The first part is devoted to a presentation of the foundations of the diagnostic stage. After discussing different approaches to conducting a diagnosis, the authors then present the well-known open systems framework, describing its components and its interdependencies, as well as the interface between the system and its environment. Here, the authors devote a full chapter to measures for assessing the effectiveness and ineffectiveness of a system. A description of other approaches derived from the open systems frame such as the Six-box model and the Stream Analysis follows along with critical comments on their advantages and limitations. The fifth chapter is a long discussion of organizational politics as they affect the intervention process, more specifically the relationship that develops and that has to be maintained between the consultant and the client organization. To assess the power of the different actors implied in the diagnostic work and the subsequent intervention, the authors develop methods for data gathering, more precisely the force field analysis model.

The second part of the book opens with a discussion of ways of analyzing specific features using a particular model in conjunction with the open systems broad frame of reference. These specific features are called "focal areas". The sixth chapter concerns the assessment of group effectiveness and the factors responsible for it. Here the authors 